\title{
1. Court mediation reform aims in a global context
}

\subsection{INTRODUCTION}

In many countries, governments have taken a special interest in introducing mediation as a means of improving judicial performance. ${ }^{1}$ Much of the world has undergone civil justice reform in the past few decades. Empirical studies of such reforms have focused on the increased usage of alternative dispute resolution in specific jurisdictions, ${ }^{2}$ how individuals access justice, ${ }^{3}$ and the role of local legal culture as an explanatory variable influencing the pace of civil case disposition. ${ }^{4}$ While court-based mediation is generally recognised as an efficient and less complex alternative to litigation, questions remain regarding its efficacy, prompting calls for continued examination. ${ }^{5}$

1 See N.M. Alexander, 'What's Law Got to Do with It? Mapping Modern Mediation Movements in Civil and Common Law Jurisdictions' (2001) 13(2) Bond Law Review Article 5; N.M. Alexander, International and Comparative Mediation: Legal Perspectives (The Hague: Kluwer Law International, 2009); B. Clark, Lawyers and Mediation (Berlin/Heidelberg: Springer, 2012); H. Genn, Judging Civil Justice (Cambridge University Press, 2010); M. Hanks, 'Perspectives on Mandatory Mediation' (2012) 35(3) University of New South Wales Law Journal 929; C. Menkel-Meadow and B. Garth, 'Process, People, Power and Policy: Empirical Studies of Civil Procedure and Courts' in P. Cane and H. Kritzer (eds), Oxford Handbook of Empirical Legal Research (Oxford University Press, 2010); J.M. Nolan-Haley, 'Mediation Exceptionality' (2010) 78 Fordham Law Review 1247.

2 See T.J. Stipanowich, "ADR and the "Vanishing Trial": The Growth and Impact of Alternative Dispute Resolution' (2004) 1(3) Journal of Empirical Legal Studies 843; T.C.W. Farrow, Civil Justice, Privatization and Democracy (2011), available at http://papers.ssrn.com.eproxy1.lib.hku.hk/sol3/papers.cfm?abstract_id 51795407 (accessed 28 November 2011).

3 See H. Genn, Paths to Justice (Oxford: Hart, 1999); Genn, Judging Civil Justice (n. 1 above).

4 See M. Heise, 'Justice Delayed? An Empirical Analysis of Civil Case Disposition Time' (2000) 50(4) Case Western Reserve Law Review 813.

5 See T. Stipanowich, 'The International Evolution of Mediation: A Call for Dialogue and Deliberation' (2015) 46 Victoria University of Wellington 
In this chapter, we examine the existing intrinsic and extrinsic rationales for introducing court-based mediation in civil justice systems. These include efficiency, reduction of caseloads, private and public sector cost reductions, as well as extrinsic factors including relational, societal and process-based considerations. In this regard, we examine a range of studies that have explored the contributions of court-based mediation to the performance of judiciaries in diverse regions, and how critiques of court-based mediation have influenced the design and implementation of reforms.

\subsection{INTRINSIC POLICY JUSTIFICATIONS CONTRIBUTING TO THE RISE IN COURT- BASED MEDIATION}

Several intrinsic factors have influenced the judicial design of court-based mediation programmes. These factors include aspirations toward reduction of caseloads and private and public sector cost reductions. In this regard, we examine a range of studies that have examined the contributions of courtbased mediation to the performance of judiciaries in diverse regions. Initial findings suggest that the achievement of the above objectives is highly dependent on key factors including proper implementation and training.

\subsubsection{Efficiency Factors Contributing to the Rise in the Use of Court- based Mediation in the Context of Civil Justice Reform}

In both developing and emerging economies, the judiciary is often challenged with a large backlog of cases, which if left unaddressed, have the potential of 'eroding individual and property rights, stifling private sector growth, and, in some cases, even violating human rights', ${ }^{6}$ since many consider access to an impartial tribunal as a basic human right. ${ }^{7}$

Law Review 1191; Pepperdine University Legal Studies Research Paper No. 2016/1, available at SSRN: http://ssrn.com/abstract52712457; see also S.I. Strong, 'Realizing Rationality: An Empirical Assessment of International Commercial Mediation' (2016) 73(4) Washington and Lee Law Review 1973; University of Missouri School of Law Legal Studies Research Paper No. 2016-07, available at SSRN: http://ssrn.com/abstract52737462.

6 M. Dakolias, Court Performance Around the World: A Comparative Perspective (Washington, DC: World Bank, 1999) pp. 1-3.

7 See European Convention for the Protection of Human Rights and Fundamental Freedoms 1950, Art. 6; American Convention on Human Rights 1969, Art. 8. 
Traditional judiciaries continue to be challenged by the complexities of court procedures and lengthy hearings which often result in a costly, inefficient and sometimes unfair system of justice.

In recent years, researchers have explored the link between economic development and judicial efficiency. In Brazil, for instance, court delay has been linked with a decrease in foreign investment by 10 per cent and a 9 per cent drop in employment. ${ }^{8}$ Similarly, in 2013, a study found that 32 million cases were pending in Indian courts, and out of these cases, 67,000 were pending in the Supreme Court. India ranks 178 out of 189 countries on 'the ease of enforcing contracts, an indicator measuring the effectiveness of national judicial systems' according to a World Bank Doing Business Report..$^{9}$ Italy ${ }^{10}$ has faced similar challenges regarding the length of trial and overall judicial inefficiency. In 2013, a study by the Organisation for Economic Co-operation and Development (OECD) revealed that the total length of a trial in Italy approached 2,866 days. ${ }^{11}$

On the basis of such efficiency concerns, while contested, ${ }^{12}$ courtannexed mediation has been implemented in many countries. Since the early 1980s, legislation in many countries has been introduced to promote the use of alternative dispute resolution such as mediation. ${ }^{13}$

Today, Singapore is often looked to as an example of a highly efficient

8 See A.C. Pinheiro, 'The Hidden Costs of Judicial Inefficiency: General Concepts and Estimates for Brazil', Address at the seminar 'Reformas Judiciales en América Latina: Avances y Obstáculos para el Nuevo Siglo', Confederación Excelencia en la Justicia, Bogotá, 1998. See also Dakolias, Court Performance Around the World (n. 6 above).

9 'Enforcing Contracts - Doing Business - World Bank Group' (2015), available at www.doingbusiness.org/data/exploretopics/enforcing-contracts/ (accessed 14 January 2016).

10 Italy along with Portugal, Greece and Malta have often been labelled as countries with inefficient justice. See 'European Justice Scoreboard' (2014) available at http://ec.europa.eu/justice/effective-justice/files/justice_scoreboard_2014_en.pdf (accessed 14 January 2016).

11 G. Palumbo et al., The Economics of Civil Justice: New Cross-Country Data and Empirics (2013), available at www.oecd.org/officialdocuments/publicdisplay documentpdf/?cote5ECO/WKP(2013)52\&docLanguage5En (accessed 14 January 2016).

12 D.R. Hensler, 'Our Courts, Ourselves: How the Alternative Dispute Resolution Movement is Re-Shaping Our Legal System' (2003-2004) 108 Pennsylvania State Law Review 165.

13 The introduction of mediation as an alternative method was introduced in the United States in 1983 when Rule 16 of the Federal Rules of Civil Procedure was amended. Since then up to 1994, the number of US States formally incorporating ADR methods grew to 27. See D. Quek, 'Mandatory Mediation: An Oxymoron? Examining the Feasibility of Implementing a Court-Mandated 
and effective judicial system. As noted by the World Bank: 'the Singapore Judiciary is presently lauded for its efficiency, its technological sophistication, its accessibility and the confidence of . . . citizens . . . in the system' ${ }^{14}$ The World Economic Forum ranked Singapore 1st out of 142 countries in terms of the efficiency of its legal framework for settling disputes. ${ }^{15}$ However, two decades ago the picture was not so positive. At that time scholars noted, 'the then-existing system of judicial administration was not designed with the fast-changing landscape in mind and it struggled to cope'. ${ }^{16}$ By the end of September 1990, 'there were still 1,963 suits begun by writ and 108 admiralty suits which were awaiting hearing dates in the High Court . . . some of these cases had been set down for hearing as early as 1982. It was then estimated that up to five years was needed before these cases could be disposed of ${ }^{3}{ }^{17}$ As a consequence, judicial reforms were implemented to improve the system. Among the solutions considered was the adoption of diversionary measures for civil disputes suited to alternative methods of resolution. Today in Singapore, 'court-based mediation takes place in the courts after parties have commenced legal proceedings. This type of mediation is mainly carried out by the State Courts for civil disputes and minor criminal offences and the Family Justice Courts'. ${ }^{18}$

Australia presents another useful example of a court-annexed mediation programme which has been described as 'one of the oldest and most successful mediation systems in the modern world'. ${ }^{19}$ Mediation in Australia is practised through court-referred programmes and serves as the primary method of civil dispute resolution. Following challenges associated with inefficiency and high costs in New South Wales (NSW) and Victoria, a mandatory mediation programme was implemented in both States, ${ }^{20}$

Mediation Programme' (2010) 11(2) Cardozo Journal of Conflict Resolution 479, available at http://cardozojcr.com/vol11no2/479-510.pdf.

14 W. Haider Malik, Judiciary-Led Reforms in Singapore: Framework, Strategies and Lessons (World Bank, 2007) p. 1. See also 17th PACI Task Force Meeting Executive Summary (2012)), available at http://reports.weforum.org/global-compet itiveness-2011-2012/ (accessed 14 January 2016).

15 Ibid.

16 H. Foo Chee, Civil Case Management in Singapore: Of Models, Measures and Justice (ASEAN Law Association, 2016), available at www.aseanlawassocia tion.org/11GAdocs/workshop2-sg.pdf (accessed 14 January 2016).

17 Ibid.

18 'Chapter 03 Mediation', available at www.singaporelaw.sg/sglaw/laws-ofsingapore/overview/chapter-3 (accessed 14 January 2016).

${ }_{19}$ W. Maclons, Mandatory Court Based Mediation as an Alternative Dispute Resolution Process in the South African Civil Justice System (University of Western Cape, 2014) p. 85.

20 Ibid. 91 . 
albeit only for certain types of cases. ${ }^{21}$ Following the decision to promote mediation, the Law Society of NSW in 1991 initiated a 'Settlement Week'22 during which time courts set aside 'their usual court rolls for a week and devoted the entire period to attempting to settle their civil matters through . . . mediation while making use of the physical court facilities' ${ }^{23}$ This initiative helped to reduce the backlog of cases, with 235 cases pending litigation ultimately successfully mediated. ${ }^{24}$

Regional implementation of court mediation, even to address efficiency concerns, has largely been dependent upon public acceptance and support. In Hong Kong, many scholars and members of the judiciary ${ }^{25}$ have considered court-encouraged mediation as a means of addressing concerns regarding extensive costs and delays. Despite the fact that mediation in general was introduced in Hong Kong in the 1980s, it hasn't yet 'been accepted widely among the public or even amongst professionals, such as business people, lawyers, clients and other stakeholders involved in disputes'. ${ }^{26}$ As a consequence, when mandatory mediation was first introduced in Hong Kong, a public consultation report recommended that it not be adopted. ${ }^{27}$ Rather, a system of voluntary mediation is currently in place and has resulted in growing familiarity with the process among the Hong Kong public.

The desire to make justice more efficient has encouraged countries to

21 Ibid. 96.

22 Inspired and based on a concept in the United States of an annual American (Washington, DC) Alternative Dispute Resolution Scheme.

23 Maclons, Mandatory Court Based Mediation (n. 19 above) p. 96.

24 Ibid.

25 'As a result, as pointed out by the Secretary for Justice of Hong Kong, Wong Yan Lung, legislators complained to the Judiciary Administrator about delays in court hearings. Wong Yan Lung therefore emphasised the application of mediation.' See S. Hilmer, 'Mandatory Mediation in Hong Kong: A Workable Solution Based on Australian Experiences' (2013) 1 China-EU Law Journal 62, available at http://dx.doi.org/10.1007/s12689-012-0016-y.

26 Ibid.

27 The Hong Kong Civil Procedure Rules were amended and came into force on 2 April 2009. However, the Mediation Practice Direction 31 (PD 31) came into force on 4 January 2010. This set of rules encouraged mediation and resulted in increasing mediation in Hong Kong, but still does not make mediation mandatory. It is important to highlight that when the topic of mandatory mediation was analysed and discussed, Proposal 64 of the Chief Justice's Working Group made the following recommendation: 'A rule should be adopted conferring a discretionary power on the judge to require parties to resort to a stated mode or modes of ADR, staying the proceedings in the meantime'. That recommendation was not successful and as a consequence was discarded. See Hilmer, 'Mandatory Mediation in Hong Kong' (n. 25 above). 
create innovative solutions, including the growing integration of mediation in court processes. Consequently, many judicial systems have implemented mediation legislation 'in courts, government departments, businesses and [within] ... industries' ${ }^{28}$ However, mandatory mediation is still viewed with caution in many jurisdictions where discretionary or categorical referral of cases for mediation may imply differing levels of compulsion. ${ }^{29}$

\subsubsection{Practical Justifications for the Use of Mediation}

As discussed in the previous section, the rise in the use of mediation is based on several justifications. Key among them include: (1) enhanced accessibility through the provision of cost-effective alternatives, and (2) reduction of delays. However, 'some writers opine that these benefits are over-stated and have not been subject to rigorous empirical scrutiny'. ${ }^{30}$ In the following

28 'Chapter 03 Mediation' (n. 18 above).
29 There are different levels of imposition when mandating mediation: '1. Categorical or Discretionary Referral with No Sanctions A prime illustration of this kind of referral is the UK Automatic Referral to Mediation pilot scheme in Central London County Court, which took place from 2004 to 2005. Although cases were automatically being referred by the courts for mediation, the disputing parties had the option to express their objections. 2. Requirement to Attend Mediation Orientation Session or Case Conference This approach is employed in Queensland, Australia, where the court may require parties to appear before the court prior to assessing whether mediation is appropriate (Section 97 of the District Court Act 1967). Similarly, in the US state of Virginia, parties are required to attend mediation orientation sessions before they are allowed to decide whether they wish to attempt mediation. 3. Soft Sanctions The United Kingdom offers the best example of this approach. The courts encourage parties to attempt ADR, and take into account the party's conduct including any unreasonable refusal of ADR or uncooperativeness during the ADR process in determining the proper order of costs. 4. Opt-Out Scheme The mandatory mediation programme in Ontario, Canada refers all civil cases, except family cases, to mediation, but provides the parties the option of seeking exemption by way of motion. 5. No Exemptions Some Australian states, such as the courts in South Australia, Victoria and New South Wales, are empowered by legislation to refer parties to mediation with or without their consent. This continuum demonstrates how the extent of coercion into mediation can vary drastically across different programs. It is this paper's assertion that mandatory mediation only becomes an oxymoron at level five of the mandatoriness continuum, i.e., when cases are referred for mediation without any provision for exemption and are accompanied by sanctions for non-compliance. It is submitted that mediation is not necessarily a contradiction in terms in all other types of mandatory mediation programs'. See Quek, 'Mandatory Mediation: An Oxymoron?' (n. 13 above) p. 490.

${ }_{30}$ K. Dayton, 'The Myth of Alternative Dispute Resolution in the Federal Courts' (1991) 76 Iowa Law Review 889; R. Posner, 'The Summary Jury Trial 
sections, we will analyse existing studies exploring the question of whether court-based mediation does in fact alleviate cost and inefficiency concerns.

\section{(i) Reduction of cost: access to justice}

When approaching the topic of costs, two perspectives must be acknowledged. The first perspective is that of the government which aims to reduce judicial costs, and secondly, that of the consumer which aims at reducing legal costs. On the one hand, when governments consider addressing costs savings they often focus on reducing judicial expenses. As such, from both a public and private perspective, governments commonly see alternative dispute resolution methods, and in particular, mediation, as a viable option for the purposes of promoting efficiency and accessibility.

With respect to the objective of costs savings, the example of the United Kingdom is noteworthy, given that the implementation of courtbased mediation was highly motivated by the objective of reducing judicial costs. Since 1980, various government administrators have expressed deep concerns over the increasing costs of legal aid. Civil legal aid in the United Kingdom was established in 1949 with the primary purpose of moderating the monetary imbalances associated with accessing justice 'so that the weak and powerless are able to protect their rights in the same way as the strong and powerful'. ${ }^{31}$ However, as the years passed the legal aid costs that had to be borne by the government were quickly increasing.

In 1990, through the Courts and Legal Services Act, a conditional fee arrangement was introduced with the purpose of reducing expenses in the civil justice system. In 1994 and 1996, the civil justice review aimed at reforming the judiciary, especially in matters related to civil legal aid. ${ }^{32}$ This policy was justified by the observation that 'the problems of cost, delay and complexity in civil justice were linked together' given that 'the principal cause of the shortcomings of the civil justice system [were]

and Other Methods of Alternative Dispute Resolution: Some Cautionary Observations' (1986) 53 University of Chichester Law Review 366. Also see Quek, 'Mandatory Mediation: An Oxymoron?' (n. 13 above) pp. 481-2, available at http://cardozojcr.com/vol11no2/479-510.pdf.; T.J. Stipanowich, 'ADR and the "Vanishing Trial": The Growth and Impact of Alternative Dispute Resolution' (2004) 1(3) Journal of Empirical Legal Studies 843.

31 H. Genn, 'What is Civil Justice For? Reform, ADR, and Access to Justice' (2013) 24(1) Yale Journal of Law and the Humanities 3, available at http://digital commons.law.yale.edu/cgi/viewcontent.cgi?article51392\&context5yjlh.

32 Ibid. 4, 5. 
to be found in the behaviour of lawyers and their adversarial tactics' ${ }^{33}$ Therefore, 'the proposed solution involved judicial case management and measures to promote early settlement' ${ }^{34}$ As a consequence, a fundamental reform postulated that Alternative Dispute Resolution (ADR) methods should be tried before and after the initiation of court proceedings. The 1995 Interim Report encouraged parties to consider ADR. This position developed when mere encouragement transformed into a requirement on the part of courts to consider 'whether the parties have unreasonably refused to try ADR or behaved unreasonably in the course of ADR'. ${ }^{35}$ Such policy direction in the United Kingdom was based primarily on public and private sector resource savings justifications. ${ }^{36}$

Similarly, in some States in the United States, financial difficulties brought about following the Financial Crisis of 2008 led to reductions in budgets allocated to the judiciary. Mediation was also seen as a method of costs savings and case management. ${ }^{37}$

However, despite the many efforts made by governments to reduce judicial costs, the question remains whether mediation is truly effective at reducing the overall costs associated with civil trials. From a global perspective, many studies have shown that the use of an alternative method such as mediation can reduce the costs of litigation. However, such findings are not conclusive and contradictory findings exist, with some

33 Ibid. 5. See also Lord Woolf, Interim Report on the Civil Justice System (Department for Constitutional Affairs, 2016), available at http://webarchive.nati onalarchives.gov.uk/+/http:/www.dca.gov.uk/civil/final/contents.htm (accessed 17 January 2016).

34 Ibid. 5.

35 Ibid. 5, 6.

36 'In the wake of the civil justice reforms and following the lead provided by Lord Woolf, several enthusiastic judges in courts around England collaborated with mediation providers to set up mediation schemes offering no- or low-cost, time-limited mediation, held on court premises for litigants who had already commenced court proceedings. The first and largest of these court-based mediation schemes was established in a county court trial centre in central London (Central London County Court) in 1996. Although the courts administered the schemes, the mediations themselves were undertaken by trained mediators, initially on a pro bono basis by trained mediators keen to try out their newly acquired skills.' See Genn, 'What is Civil Justice For?' (n. 31 above) pp. 7-8. See also Woolf, Interim Report on the Civil Justice System (n. 33 above).

37 From one perspective, 'The enthusiasm for mediation is inspired in large part by economics as the state's court system struggles with cutbacks and layoffs.' See further 'ACDR: State Hopes Mediation Can Ease Court Overload' (2011), available at www.alabamaadr.org/web/media/articles/111018_MA_Mediation_Week. php (accessed 17 January 2016). 
studies including important work by Hensler showing that differences in costs savings may be negligible if they exist at all, ${ }^{38}$ while others show some reduction in costs. At present, no unified view exists on the question of private sector costs savings.

With respect to the question of costs savings on the part of litigants, a study conducted after the introduction of mediation in the former Bosnia and Herzegovina showed that after a year of implementing the court mediation programme, associated costs were almost 50 per cent less than those associated with court litigation. ${ }^{39}$ In North America, according to Barkai and Kassebaum, mediation 'saved about US\$500 per party in the United States ${ }^{40}$ and about US $\$ 6,000$ per case in Canada'. ${ }^{41}$ Research by Rosenberg and Folberg ${ }^{42}$ reported that while about 40 per cent of parties believed that they saved money with mediation, 38 per cent of attorneys and parties believed that mediation added about US $\$ 4,000$ on average to the cost of litigation. Stipanowich provides an extensive analysis of cost impacts of various forms of mediation in the US, finding that costs savings exist in some contexts and Wissler reports mixed results on general civil mediation costs savings. ${ }^{43}$

When examining mandatory court-based mediation, the story varies. A recent study found that 'many cases that attempt to use ADR, mainly

38 D. Hensler, 'In Search of Good Mediation' in J. Sanders and V.L. Hamilton (eds), Handbook of Justice Research in Law (New York:, Springer, 2001); See: T.J. Stipanowich, "ADR and the "Vanishing Trial": The Growth and Impact of Alternative Dispute Resolution' (2004) 1(3) Journal of Empirical Legal Studies 843 for a comprehensive meta-survey of mediation impact and experience in the US.

39 In a year the direct costs of mediation had averaged US $\$ 225$, about 50 per cent of the costs of litigation (c. US\$470). See I. Love, 'Settling Out of Court: How Effective is Alternative Dispute Resolution?', available at www.openknowledge. worldbank.org/bitstream/handle/10986/11055/678050VP00PUBL0Setting0out0of 0court.pdf?sequence51 (accessed 17 January 2016).

40 Ibid. See also, J. Barkai and G. Kassebaum, Hawaii's Court-Annexed Arbitration Programme, Final Evaluation Report (Peace Institute of Hawaii, 1992), available at www.peaceinstitute.hawaii.edu/resources/_epubs/Hawaiis-Court-Annex ed-Arbitration-Programme-Final-Evaluation-Report.pdf (accessed 17 January 2016).

41 R. Hann and C. Baar, Evaluation of the Ontario Mandatory Mediation Programme (Rule 24.1): Executive Summary and Recommendations (Ministry of the Attorney General, 2001), www.attorneygeneral.jus.gov.on.ca/english/courts/ manmed/exec_summary_recommend.pdf (accessed 17 January 2016).

42 J. Rosenberg and J. Forlberg, 'Alternative Dispute Resolution: An Empirical Analysis' (1994) Stanford Law Review 46.

43 See: T.J. Stipanowich, 'ADR and the "Vanishing Trial": The Growth and Impact of Alternative Dispute Resolution' (2004) 1(3) Journal of Empirical Legal Studies 843; see also Love, 'Settling Out of Court' (n. 39 above); Hensler, 'In Search of Good Mediation' (n. 38 above). 
under mandatory mediation, end up in court anyway', so the real cost saving is not clearly established. ${ }^{44}$ Supporting this finding, it was reported that in the case of London's court-referred mediation programme, of the 1,232 cases referred to the programme, only 14 per cent were mediated; the rest went back to court. Overall, 'the settlement rate was 55 per cent in no-objection cases, and 48 per cent in cases where parties were persuaded to mediate. The study estimated that for cases that failed to reach settlement through ADR, total legal costs were US $\$ 2,000-4,000$ higher than they would have been if no attempt had been made to use ADR ${ }^{45}$ In North Carolina, a report measuring the outcomes of a court-sponsored mediation programme for civil claims showed that its programme did not meet its cost-saving goals as expected; and satisfaction with mediation was no greater than with conventional settlement, though those who settled, whether via mediation or otherwise, were more satisfied than those who went to trial. ${ }^{46}$

There is no doubt that in theory, mediation can reduce the costs of litigation. At the same time, 'mediation can save government money by resolving conflicts outside of or earlier in the court system. This allows court resources to be re-allocated to other matters. More indirectly, mediation saves civil litigants and families legal and court fees' ${ }^{47}$ Yet, given the mixed findings in terms of overall costs savings, particularly for mandated cases that require further litigation, questions still remain as to whether court-referred mediation does in fact reduce litigation costs. Studies thus far show mixed results and tend to show that voluntary mediation can be more successful than mandatory mediation in reducing costs, as will be discussed later in this chapter.

\section{(ii) Reduction of caseload and delay}

Court-centred case congestion contributes to the delay of justice. One of the principal justifications for reforming systems of civil justice is the

\footnotetext{
44 See Love, 'Settling Out of Court' (n. 39 above). See also H. Genn et al., Twisting Arms: Court Referred and Court Linked Mediation Under Judicial Pressure, Ministry of Justice Research Series 1/07 (2007), available at www.ucl.ac. uk/laws/judicial-institute/files/Twisting_arms_mediation_report_Genn_et_al_1. pdf (accessed 17 January 2016).

45 See Love, 'Settling Out of Court' (n. 39 above). See also, Genn et al., Twisting Arms (n. 44 above).

46 See Love, 'Settling Out of Court' (n. 39 above).

47 S. Vander Veen, A Case for Mediation: The Cost-Effectiveness of Civil, Family, and Workplace Mediation (Mediate BC, Dispute Resolution and Design, 2014), available at www.mediatebc.com/PDFs/1-52-Reports-and-Publications/Th e-Case-for-Mediation.aspx (accessed 17 January 2016).
} 
reduction of caseloads. The story of India is particularly noteworthy in this regard. As discussed above, the Indian justice system has been struggling for the last 20 years with extensive delays due to a high volume of pending cases. A study conducted by the Ministry of Law in India found that 'at the current rate it will take 324 years to dispose of the backlogs of cases in Indian courts' ${ }^{48}$ Various justifications have been put forward to explain the source of the issue, including the population explosion, a lack of human resources in the judicial system, lack of adequate training and changes to the pattern of litigation. ${ }^{49}$

In 1987, at the trial court level, India promulgated the Legal Services Authorities Act by which court mediation was introduced. The Act came into effect in 1995 and was implemented through specialized courts called 'Lok Adalats'. ${ }^{50}$ Mediation operated mostly on a consensual basis and according to Dr Adarsh Sein Anand, former Chief Justice of India, 'Lok Adalats' had settled over 97 lakh ${ }^{51}$ legal matters throughout the country by 1999. ${ }^{52}$ Due to this success, in 1999 the Indian Parliament passed the Civil Procedure Code requiring that trial courts refer disputes for settlement through mediation and other alternative means of solving conflict. ${ }^{53}$ The passage of this Code alongside support from the Chief Justice of India B.N. Kirpa $^{54}$ has led to the proliferation of court-based mediation throughout India. ${ }^{55}$ While the Indian legislature has made significant provision in law to facilitate the introduction of court-annexed mediation, nevertheless

48 Indian Institute of Arbitration and Mediation (IIAM), Community Mediation Service, available at www.arbitrationindia.org/pdf/brochure_cms.pdf (accessed 17 January 2016).

49 T. Hussain Jillani, 'Delayed Justice and the Role of ADR', p. 5, available at www.supremecourt.gov.pk/ijc/articles/7/1.pdf. (accessed 17 January 2016).

50 People's Court: 'Lok' refers to 'people' and 'Adalat' means court. India has a long tradition and history of such methods being practised in the society at grass roots level.

$51 \quad$ Lakh $=100,000$.

52 Hussain Jillani, 'Delayed Justice and the Role of ADR' (n. 49 above) p. 5 .

53 Supreme Court of India, Manual for Training Mediation, available at http:// supremecourtofindia.nic.in/MEDIATION\%2520TRAINING\%2520MANUAL $\% 2520 \mathrm{OF} \% 2520$ INDIA.pdf (accessed 17 January 2016).

54 Bhupinder Nath Kirpal (B.N. Kirpal) was appointed Chief Justice of the Gujarat High Court in 1995 and later on he was appointed as Judge of the Supreme Court of India, and became Chief Justice of India in May 2002, serving from 6 May 2002 until his retirement on 7 November 2002.

55 Justice M. Shah, 'Study of the American Legal System for Procedural Reforms in Civil Courts in India, available at http://gujarathighcourt.nic.in/Articles/ msshah.pdf (accessed 17 January 2016). 
implementation of such legislation in practice has been limited. ${ }^{56}$ Scholars believe that systematic training of mediators is required in order to achieve the legislative objectives. At present, existing challenges include the minimal availability of effective court-annexed mediation services, the lack of training to handle complex commercial and civil cases, and the lack of systems to monitor and evaluate the disposition of cases sent for mediation..$^{57}$

The Netherlands likewise presents a useful illustration of a judiciary seeking to address case backlog. During the 1990s, in an effort to address court delay, the judiciary promoted court-annexed mediation. A study analysing the effects of the programme found that 'about $5 \%$ of the cases suitable for mediation were resolved and concluded by court-referred mediation'. ${ }^{58}$ The study showed that while a small number of cases proceeded to mediation, each successful mediation decreased the work of the courts given 'the time saved that the court would otherwise have to spend drawing up a judgement, hearing testimony and reviewing written exchanges of statements' ${ }^{59}$

Many studies have shown that mediation can save time for courts and parties, ranging from several months to several years. In Colombia, a study examining its court mediation programme ${ }^{60}$ showed that in 2001 tenant eviction cases took 15 months on average in court but only four months in mandatory conciliation. ${ }^{61}$ A study by Hann and Baar $^{62}$ analysing the

56 Justice S.B. Sinha has stated the following: 'The currently available infrastructure of courts in India is not adequate to settle the growing litigation within reasonable time. Despite the continual efforts, a common man may sometimes find himself entrapped in litigation for as long as a life time, and sometimes litigation carries on even to the next generation. In the process, he may dry up his resources, apart from suffering harassment. Thus, there is a chain reaction of litigation process and civil cases may even give rise to criminal cases. Speedy disposal of cases and delivery of quality justice is an enduring agenda for all who are concerned with administration of justice. In this context, there is an imminent need to supplement the current infrastructure of courts by means of Alternative Dispute Resolution (ADR) mechanisms'.

57 N. Bhatt, Legislative Initiative for Court Annexed Mediation in India (2003), available at www.mediate.com/articles/bhattn.cfm (accessed 17 January 2016).

58 B. Niemeijer and M. Pel, 'Court-Based Mediation in the Netherlands: Research, Evaluation and Future Expectations' (2005) 110(2) Pennsylvania State Law Review 365.

59 Ibid.

60 A. Alvares de la Campa, The Private Sector Approach to ADR: Commercial ADR Mechanism in Colombia (Investment Climate Department, World Bank Group, 2009) pp. 5-10, available at www.wbginvestmentclimate.org/uploads/Priva te $\% 20$ Sector $\% 20$ Approach $\% 20$ to $\% 20$ Commercial $\% 20$ ADR_ $\% 20$ the $\% 20$ case $\% 20$ of \%20Colombia\%20.pdf (accessed 19 January 2016).

61 Ibid.

62 Hann and Baar, Evaluation of the Ontario Mandatory Mediation Programme (n. 41 above). 
effects of court-referred mediation in Canada found that mandatory mediation programmes resulted in more cases being settled sooner. At 'six months, for example, 25 per cent of cases under the mandatory mediation rule were disposed, compared with only 15 per cent of control cases' ${ }^{63}$ Similarly, Wissler ${ }^{64}$ reported that in five studies of appellate cases, the time to disposition was one to three months shorter for cases assigned to mediation than for other cases'. ${ }^{65}$

In addressing court delay, pilot programming followed by the introduction of legislation, as exemplified in Canada, has been considered an effective model for designing court-based programmes. In 1999, in Toronto and Ottawa, a two-year pilot rule was introduced in the Ontario Court Rules for the Ontario Superior Court of Justice ${ }^{66}$ making mediation mandatory. According to a study examining 3,000 mediated cases alongside a control group, the study concluded that mandatory mediation under the rule resulted in significant reductions in the time taken to dispose of cases, decreased costs to litigants, a higher proportion of cases (roughly 40 per cent overall) being completely settled, and a larger further group partially settled, early in the litigation process. ${ }^{67}$ The same study also reported other benefits to litigants in cases that did not end up settling. The same study also found that 'lawyers estimated their clients' cost savings to be $\$ 10,000$ or more per case in $38 \%$ of mediated cases, [and] less than $\$ 5,000$ in $34 \%$ of them, and from $\$ 5,000-\$ 10,000$ in $28 \%$ of mediated cases' ${ }^{68}$ As a result of the pilot programme, further legislation was developed, further integrating mediation into the civil justice system.

Additional findings from studies in Australia likewise suggest that court-based mediation programmes have contributed to reduction in delays. A study of the mandatory court-referred mediation programme in New South Wales found that at least half of the cases referred to mediation successfully resulted in settlement, thereby significantly reducing the

\footnotetext{
63 See Love, 'Settling Out of Court' (n. 39 above).

64 R. Wisler, 'The Effectiveness of Court-Connected Dispute Resolutions in Civil Cases' (2004) 22(1-2) Conflict Resolution Quarterly, available at http:// onlinelibrary.wiley.com/doi/10.1002/crq.92/abstract.

65 See Love, 'Settling Out of Court' (n. 39 above).

66 Rule 24.1: this Rule provides for mandatory mediation in specified actions, in order to reduce costs and delay in litigation and facilitate the early and fair resolution of disputes. See 'Law Document, English View', available at www. ontario.ca/laws/regulation/900194 (accessed 19 January 2016).

67 Hann and Baar, Evaluation of the Ontario Mandatory Mediation Programme (n. 41 above).

68 Ibid.
} 
courts' remaining caseload. ${ }^{69}$ In Australia, a 2008 study reported that mandatory civil mediation for cases under AUS\$10,000 showed a settlement rate of 86 per cent, and of those cases, 32 per cent settled before mediation and 12 per cent settled shortly thereafter. The overall effect was a significant reduction in judicial and administrative workload. ${ }^{70}$

While, as noted above, several studies have established the existence of a considerable time reduction through court-referred mediation programmes, other reports have established no significant reduction in duration of cases. In 1996, a study conducted by RAND reported that there was 'no strong statistical evidence that the mediation or neutral evaluation programs significantly affected time to disposition, litigation costs or attorney view of fairness and satisfaction'.$^{71}$ However, later studies have suggested a wider base of programmes be examined to provide additional insights. ${ }^{72}$ Bergman and Bickerman ${ }^{73}$ noted that in the case of court-mediation programmes, well-run ADR programmes can reduce cost and time. Therefore, success and achievement of goals in mediation largely depend on implementation and training efforts.

Given mixed results regarding the overall impact of mediation in reducing cost and duration of civil cases, additional questions must be addressed. These include how efficacy in mediation can be measured and what might define success and efficiency. A study conducted by the National Alternative Dispute Resolution Advisory Council (NADRAC) and Australian Institute of Judicial Administration (AIJA) in Australia provides a number of helpful insights in this regard noting, 'success can have a range of possible meanings and be measured in many different ways ... Even with ... relatively narrow measures [i.e. settlement rates, party satisfaction], there are substantial limits on the ability of empirical research to establish clear referral criteria' ${ }^{74}$ Many view success as most

69 Maclons, Mandatory Court Based Mediation (n. 19 above) pp. 101-2.

70 Vander Veen, $A$ Case for Mediation (n. 47 above).

71 T. Stipanowich, "ADR and the "Vanishing Trial": The Growth and Impact of 'Alternative Dispute Resolution' (2004) 1(3) Journal of Empirical Legal Studies 852, available at http://papers.ssrn.com/sol3/papers.cfm?abstract_id51380922; D. Hensler, 'In Search of Good Mediation' (n. 38 above).

72 The critiques of this report were based on the premise that the sampled programmes were not representative of other programmes in operation. See further, Stipanowich, "ADR and the "Vanishing Trial"" (n. 71 above) p. 852.

73 See E. Bergman and J. Bickerman, Court-Annexed Mediation: A Critical Perspective on Selected State and Federal Programs (Pike and Fischer, Inc., 1998).

74 K. Mack, Court Referral to ADR: Criteria and Research (Attorney General Department of Australia 2003) pp. 2-3, available at www.ag.gov.au/LegalSystem/ AlternateDisputeResolution/Documents/NADRAC $\% 20$ Publications/Court $\% 20$ 
importantly measured through 'high client satisfaction' often resulting in high quality mediation programmes entailing 'highly trained, debriefed, problem-solving mediation services staffed by well-paid mediators, who use an intake process'. ${ }^{75}$ Exploring these insights further, in the following sections, we will examine other justifications for the use of court mediation beyond mere costs savings and judicial efficiency.

\subsubsection{Extrinsic Factors Contributing to the Use of Court-based Mediation}

The following section examines key extrinsic considerations in implementing court-based mediation programmes beyond issues of time and costs savings. These factors include relational, societal and process-based contributions.

\section{(i) Relational justifications}

For disputing parties who hope to maintain a lasting relationship, mediation often presents an attractive approach. Many have discussed its efficacy in contributing toward both the health and positive transformation of relationships between individuals and in the context of deliberative participation in policy-making. ${ }^{76}$ In some cases, mediation presents 'a special advantage when parties have on-going relations that must continue after the dispute is managed, since the agreement is by consent and none of the parties should have reason to feel that they are the losers' ${ }^{77}$ Relationbased justifications are particularly relevant to family disputes, conflicts between neighbours, workplace disputes and conflicts between business partners. Even in commercial cases where one party does not want to lose a client, 'mediation creates a foundation for resuming the relation after the particular issue has been resolved' ${ }^{78}$

During the process of mediation, parties have an opportunity to gain an understanding of one another's motives, needs and interests. This understanding can often improve a given relationship going forward. ${ }^{79}$

Referral\%20to\%20ADR\%20-\%20Criteria\%20and\%20Research.PDF (accessed 19 January 2016).

75 Ibid. $2-3$.

76 L.P. Love and E. Galton, Stories Mediators Tell (ABA Book Publishing, 2012); H.N. Aragaki, 'Deliberative Democracy as Dispute Resolution: Conflict, Interests, and Reasons' (2009) 24(3) Ohio State Journal on Dispute Resolution 406.

77 Y. Shamir, Alternative Dispute Resolution Approaches and Their Application (UNESCO, 2003) p. 24.

78 Ibid.

79 R.E. Emery, D. Sbarra and T. Grover, 'Divorce Mediation: Research and Reflections' (2005) 43(1) Family Court Review 22; L.P. Love and E. Galton, Stories Mediators Tell (ABA Book Publishing, 2012). 
Mediation has also been linked with improving workplace relations in appropriate circumstances. For example, in the case of the Canadian Public Service Staff Relations Board, which established an employee mediation service, ' 500 files had been mediated and reported at an $85 \%$ success rate'. ${ }^{80}$ Later a 'modified version of the pilot programme ... [became] a permanent part of the Board's dispute resolution processes' ${ }^{81}$ In addition, according to a 2011 Chartered Institute of Personnel and Development report examining conflict management in the workplace, mediation programmes were found to be beneficial in helping improve relationships between workers and colleagues. ${ }^{82}$ Similarly, mediation in the workplace has been found to provide a 'cost-effective method for addressing the full economic consequences of conflict including lost productivity, absenteeism, employee turnover, and failed projects that translate into approximately $\$ 359$ billion dollars a year in wages alone in the United States of America'. ${ }^{83}$ Mediation for workplace conflicts involving civil rights issues is not without critiques, as will be discussed in the final section.

\section{(ii) Process considerations}

When it comes to process considerations, very often mediation is selected because of the opportunity it provides parties to design and contribute to the resolution of conflict. Parties tend to report higher levels of satisfaction when a settlement is reached through a participatory process. Underlying interests are often addressed, in contrast with judicial-based outcomes which must be based on strict legal principles that may ignore underlying needs. ${ }^{84}$

In general, mediation can be a flexible method of resolution 'adapted to meet the needs of ... parties ... in formulating a solution' 85 The parties decide how to manage the process and agree on the relevant procedural

80 Ibid.22-3. See also, G. Baron, 'Public Service Staff Relations Board Mediation Programme' in Canadian Bar Association's Possibilities Newsletter (2003).

81 Emery et al., 'Divorce Mediation: Research and Reflections' (n. 79 above) pp. 22-3. See also, Baron, 'Public Service Staff Relations Board Mediation Programme' (n. 80 above).

${ }_{82}$ Vander Veen, $A$ Case for Mediation (n. 47 above) p. 25.

83 Ibid.

84 R. Zeinemann, 'The Characterisation of Public Sector Mediator' (2003) 24(2) Environs Law 51, available at http://environs.law.ucdavis.edu/volumes/24/2/ articles/zeinemann.pdf.; T.J. Stipanowich, "ADR and the "Vanishing Trial": The Growth and Impact of Alternative Dispute Resolution' (2004) 1(3) Journal of Empirical Legal Studies 843; L.P. Love and E. Galton, Stories Mediators Tell (ABA Book Publishing, 2012).

85 Shamir, Alternative Dispute Resolution Approaches and Their Application (n. 77 above) pp. 24-5. 
rules. This 'may involve the choice over location of the mediation, the time frame, the people who are to be involved, the selection of acceptable objective criteria, and many other choices related to the process' ${ }^{86}$ This approach appeals to parties who wish to be partners in the process of resolving their conflict and participate in crafting the resolution of their dispute. Moreover, given its flexibility, parties are enabled to present their arguments in an informal manner, not bound by legal procedures. ${ }^{87} \mathrm{~A}$ study conducted in the Netherlands found that when parties are in control of the resolution process, they tend to reach agreement more easily. This applies to situations in which parties wish to craft their own outcomes, rather than 'follow the advice of the judge'. 88

However, some researchers have noted that the increasingly formalized rules associated with court-based mediation have inhibited the key advantages of mediation, namely, its informality and flexibility. Some scholars have noted that formalized court mediation rules inhibit the potential of mediation since: 'case management, while important to the justice system, was never really the goal of mediation as a distinct social process. In effect, connection with the courts had distorted an incidental benefit of mediation into its primary goal'. ${ }^{89}$

\section{(iii) Societal considerations}

Mediation skills, applied both in a court-based context and at the community and international level, have the potential of transforming local and international conflicts into peaceful agreements, thereby in some contexts contributing towards greater social harmony. The skills learned in court-referred settings are similar to those relevant to both local and international conflict and thus have potential positive spill-over effects in the wider society.

Similar to the potentially positive interpersonal relational benefits of mediation discussed above, when examining the impact of mediation in addressing community-based conflicts, particular benefit has been associated with the opportunity for affected community members to participate in crafting relevant solutions. Through this process, community members take part in ensuring that key issues are appropriately addressed and resolved. The application of community-based mediation expanded in

\footnotetext{
86 Ibid. $24-5$.

87 Ibid.

88 Niemeijer and Pel, 'Court-Based Mediation in the Netherlands' (n. 58 above) p. 360 .

89 D. Della Noce, 'Mediation Theory and Policy: The Legacy of the Pound Conference' (2002) 17(3) Ohio State Journal on Dispute Resolution 554, 555.
} 
Canada in the $1980 \mathrm{~s},{ }^{90}$ to the extent that by 1996,26 jurisdictions across Canada had established such programmes. Similarly, the Indian Institute of Arbitration and Mediation (IIAM) established a mediation service to address the needs of community members by providing a localized resolution platform staffed by locally trained individuals. ${ }^{91}$ In Hong Kong, the Mediation Council in Hong Kong introduced a mediation Pilot Scheme 2002 focused on addressing disputes involving neighbourhood, employment, contract, urban redevelopment and environmental issues. ${ }^{92}$ Such programmes have proliferated in recent years, given the growing numbers of individuals who have been exposed to mediation skills training.

At the international level, mediation has, in some cases, contributed to the resolution of both armed and unarmed conflicts, thus advancing global peace and, as a consequence, alleviating suffering caused by war. Several notable examples demonstrate the efficacy of mediation in contributing to international peace. Most well documented was the Camp David mediation ${ }^{93}$ in which former President Jimmy Carter facilitated a mediation process that resulted in achieving a resolution to the conflict engulfing Israel and Egypt. ${ }^{94}$

Mediation has been put forward as a key mechanism used by the United Nations in addressing global conflicts. In 2010, the governments of Finland and Turkey convened a Group of Friends of Mediation at the United Nations with the intention of raising 'awareness within the international community of the importance of mediation as a means of conflict prevention and resolution' and to 'help build mediation capacity and expertise both within the United Nations and also in regional organizations, which are often most well-placed to assume such a mediating role in their own area of responsibility'. ${ }^{95}$ Today the initiative is supported by 37 United

90 Church Council on Justice and Corrections, Restorative Justice (1996), available at www.johnhoward.ab.ca/pub/C26.htm\#comm (accessed 19 January 2016).

91 IIAM Community Mediation Service (n. 48 above).

92 Government of the Hong Kong Special Administrative Region, Department of Justice, Report of the Working Group on Mediation (2010), available at www. gov.hk/en/residents/government/publication/consultation/docs/2010/Mediation. pdf (accessed 19 January 2016).

93 J. Carter, Keeping Faith: Memoirs of a President (Fayetteville, AR: University of Arkansas Press, 1995) pp. 284-337.

94 The Nobel Peace Prize for 2002 to Jimmy Carter, Press Release, available at www.nobelprize.org/nobel_prizes/peace/laureates/2002/press.html (accessed 19 January 2016).

95 'Engineering Peace: Achieving the Promise of Mediation in the World's Most Difficult Conflicts', available at www.mediate.com/articles/engpeace.cfm\#_ edn7 (accessed 19 January 2016). 
Nations Member States in addition to seven regional multilateral organizations (the African Union, ASEAN, Arab League, Organisation of Islamic Cooperation, European Union, Organisation for Security and Co-operation in Europe and Organization of American States). Since that time, the initiative has brought international focus to the benefits of mediation in contributing to world peace. In 2011 'the United Nations General Assembly adopted a Resolution on Strengthening the Role of Mediation in the Peaceful Settlement of Disputes, Conflict Prevention and Resolution' ${ }^{96}$ A follow-up report on the implementation of this resolution was issued in $2012 .{ }^{97}$

Such initiatives have further promoted the use of mediation on a global level. As a result, the demand for mediation has increased, such that 'multilateral organizations now need to translate that interest ... into the development of their capabilities as convenors, promoting understanding of what mediation is and how and why it works, and most critically developing a strong cadre of highly-trained, multi-talented, inter-cultural peace mediators whose skills are certified and who can be identified and valued easily' ${ }^{98}$ The group Mediators Without Borders has been working to develop mediation capacity around the globe. In one case, through the assistance of trained mediators in Nigeria, individuals have contributed to 'address[ing] 'ethnic and class conflict that have turned to violent confrontation and terrorist acts' ${ }^{99}$

Therefore, beyond court backlog reduction and costs and time savings, it is clear that mediation has potentially wider extrinsic spill-over benefits at both the local and international levels in preserving relationships, engaging individuals in a process of crafting and implementing solutions, and developing long-term skills to address ongoing and future conflicts.

\subsection{SCHOLARLY CRITIQUES OF THE RISE OF COURT-BASED MEDIATION}

As discussed above, mediation has the potential to provide both direct and indirect benefits to judiciaries, individuals and society. It is not

\footnotetext{
96 Ibid.

97 Report on Strengthening the Role of Mediation in the Peaceful Settlement of Disputes, Conflict Prevention and Resolution, United Nations Res.A/66/811, available at http://peacemaker.un.org/node/79 (accessed 19 January 2016).

98 'Engineering Peace' (n. 95 above).

99 International Sustainable Peace Alternative Dispute Resolution Center Initiative (Mediators Without Borders, 2012) p. 1, available at www.mediators withoutborders.org/wp-content/uploads/2012/02/Research-FindingsFinal.pdf (accessed 19 January 2016).
} 
surprising, therefore, that mediation has become a major policy approach in civil justice reform programmes. However, court-based mediation is not without criticisms, principally those challenging its consistency within institutionalized settings, its potential to obstruct access to justice, and its inappropriateness to particular classes of cases.

\subsubsection{Inconsistency with Institutionalized Court-based Settings}

Given that one of the core principles of mediation is voluntariness, some scholars have observed that 'attempts to impose a formal and involuntary process on a party may potentially undermine the raison d'être of mediation'. ${ }^{100}$ Further questions have been raised as to whether the 'full benefits of mediation [can] be reaped when parties are left to participate in it un-voluntarily'. ${ }^{101}$ The argument against compulsory mediation is based on the view that 'mandatory mediation impinges upon parties' self-determination and voluntariness, thus undermining the very essence of mediation'. ${ }^{102}$ Furthermore, it has been suggested that 'coercion into the mediation process invariably leads to coercion to settle within the mediation process, which leads to unfair outcomes' and therefore may be contrary to social justice. ${ }^{103}$ Several studies have found that disputants are most satisfied with the mediation process when it is conducted in a noncoercive manner and attentive to parties' interests. ${ }^{104}$

There is no doubt that court-referred mediation increases usage rates. For example, in England prior to the introduction of its Civil Procedure Rules, mediation was selected in 160 out of 4,500 cases or 3.5 per cent of the time. Following the introduction of the Rules, 'which empowered the courts to encourage the use of ADR (with cost sanctions), the number of commercial disputes referred for mediation increased by 141 per cent'. ${ }^{\prime}{ }^{105}$ Some observers have established that despite the fact that court-based mediation might require parties to mediate, this does not contradict a parties' freedom to reach a voluntary agreement.

Some scholars have also challenged what is viewed as an over-extension

\footnotetext{
100 Quek, 'Mandatory Mediation: An Oxymoron?' (n. 13 above) p. 481.

101 Ibid. 484.

102 Ibid.

103 C. Guthrie and J. Levin, 'A Party Satisfaction Perspective on a Comprehensive Mediation Statute' (1998) 13(3) Ohio State Journal On Dispute Resolution 885, 892, 893, available at https://discoverarchive.vanderbilt.edu/bitstream/handle/1803/7392/ Party_Satisfaction_Perspective.pdf?sequence51.

104 Ibid.

105 Quek, 'Mandatory Mediation: An Oxymoron?' (n. 13 above) p. 483.
} 
of court-based mediation programmes based on the view that once the objective of public education has been fulfilled, court mediation should resume its voluntary character. In the United States, it has been suggested that 'mandatory mediation might have been appropriate in the United States as a remedial measure to get the ADR ball rolling in the 1970s and 1980s'. ${ }^{106}$ However, with the passage of time, 'court compulsion is no longer needed since the ADR movement in the United States is more mature'. ${ }^{107}$ Such scholars submit that 'court-mandated mediation should only be a short-term measure utilized in jurisdictions where mediation is relatively less well developed, and that this expedient should be lifted as soon as the society's awareness of mediation has reached a satisfactory level' ${ }^{108}$ This point is based on the claim that mandatory mediation could be contrary to the civil and human rights of the parties, which will be explored in greater detail in the following section.

\subsubsection{Access to Justice}

In addition to concerns regarding compulsion and over-extension, some scholars have suggested that mandatory mediation might hamper access to impartial justice. This view was adopted by the English courts in the case of Halsey v. Milton Keynes General NHS Trust, where it was held that 'to oblige truly unwilling parties to refer their disputes to mediation would be to impose an unacceptable obstruction on their right of access to courts' ${ }^{109}$

While the right of access to court is guaranteed under Article 6 of the European Convention on Human Rights, ${ }^{110}$ the passage of the EU Mediation Directive (2008/52) which provides for the implementation of either voluntary or mandatory court mediation for cross-border disputes and subsequent Court of Justice of the European Union (CJEU) litigation, have established that mandatory court mediation is not inconsistent with the right of access to a fair and impartial tribunal. ${ }^{111}$ In defending the view that mandated mediation does not contradict basic human rights, some scholars have pointed out that:

\footnotetext{
106 Ibid. 484.

107 Ibid.

108 Ibid.

109 Ibid. 485.

110 European Convention on Human Rights, Art. 6: Right to a Fair Trial, available at www.echr.coe.int/Documents/Convention_ENG.pdf (accessed 19 January 2016).

111 See generally www.libralex.com/publications/the-impact-o-the-EU-mediati on-directive.
} 
an individual may be told to attempt the process of mediation, but that is not tantamount to forcing him to settle in the mediation. As the coercion in mandatory mediation only relates to requiring that parties try to reach an agreement to resolve their dispute. Therefore, the individual is not being denied access to court because mandatory mediation is not being ordered in lieu of going to court. Instead, the parties' access to court is only delayed; the parties have the liberty to pursue litigation once again if mediation fails. ${ }^{112}$

Taking up this view, the government of Hong Kong in its report on civil reform stated 'mandatory mediation does not deny access to justice, but merely defers it'. ${ }^{113}$ Therefore:

only an order that the parties resort to ADR in lieu of having their case decided in court may run afoul of Article 35 of the Hong Kong Basic Law, which guarantees the right of access to the courts. A more significant issue with regard to this objection is ensuring that such access to justice is not unduly deferred (through, for instance, draconian sanctions), as well as ensuring that the quality of mandatory mediation is monitored closely so as not to unfairly compel parties to incur additional costs for mediation. ${ }^{114}$

While it can be argued that there exists a thin line separating compelled mediation from denial of court access, nevertheless, in general, given parties' subsequent right to proceed to trial, such concerns appear to have been largely addressed by recent court cases. ${ }^{115}$

\subsubsection{Mediation and Public Policy}

Modern court mediation as a policy approach has not been without critique. Chief among these arguments is that settlement does not result in the development of public goods, including rules of precedent, advocacy skills, publication of facts and enhanced authority of courts as achieved through adjudication. ${ }^{116}$ This argument explicates Fiss's view that adjudication is a central part of political life because it contributes to the articulation of public values. ${ }^{117}$ Unlike Fiss, some scholars such as Luban acknowledge that only a small portion of disputes are occa-

\footnotetext{
112 Quek, 'Mandatory Mediation: An Oxymoron?' (n. 13 above) p. 486.

113 Ibid. 498-9.

114 Ibid.

115 Ibid. 492-3.

116 D. Luban, 'Settlements and the Erosion of the Public Realm' (1995) 83

Georgetown Law Journal 2619.

117 Ibid.
} 
sions for structural transformation, ${ }^{118}$ and therefore endorses settlement approaches that are open to sunshine laws. ${ }^{119}$ Others have noted that rather than a blanket challenge on policy grounds, court-mandated mediation may be unsuitable for particular case types. For example, when legal precedent is sought or a matter of public interest is raised, judicial determination may be more appropriate than mandatory courtreferred mediation. ${ }^{120}$ For example, some research has pointed to the dangers of civil rights employment mediation subsuming 'legal rights under managerial interests'. ${ }^{121}$

Out of court settlement ${ }^{122}$ has also been challenged based on the view that such processes enlarge social disputes, ${ }^{123}$ deformalize justice, diffuse legitimate indignation of parties ${ }^{124}$ and pose an increased risk of outcomes coloured by prejudice. ${ }^{125}$ Similarly, Grillo argues that women's interests may be undermined in the mediation process ${ }^{126}$ due to its lack of context, absence of rules and minimization of fault. ${ }^{127}$ Cases in which there is a clear power imbalance between parties, and where the mediator is not sufficiently trained to address such imbalance, some have suggested, may likewise raise procedural justice concerns. ${ }^{128}$ In New South Wales and Victoria, for example, 'despite the long standing practice of mandatory court-referred mediation', due to the fact that courts have discretion in 'ordering appropriate cases to mediation, the court may select broad categories of cases as being amenable to mediation, thereby failing to take into consideration the unique circumstances of each case and vast divergences between disputes and parties, as well as the different needs of litigants'. ${ }^{129}$

\footnotetext{
118 Ibid.

119 Ibid

120 See O. Fiss, The Forms of Justice, Faculty Scholarship Series Paper 1220 (1979); O. Fiss, 'Against Settlement' (1984) 93(6) Yale Law Journal 1073.

121 See L. Edelman, H. Erlanger and J. Lande, 'Internal Dispute Resolution: The Transformation of Civil Rights in the Workplace' (1993) 27(3) Law and Society Review 497.

122 R. Delgado, 'ADR and the Dispossessed: Recent Books about the Deformalization Movement' (1988) 13 Law and Social Inquiry 145.

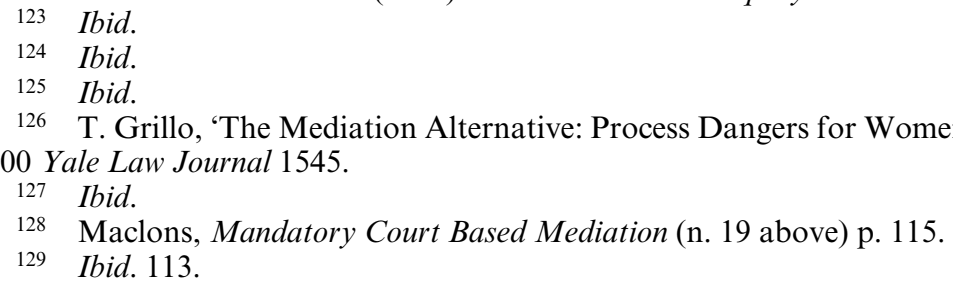




\subsubsection{Response to Critiques of Court Mediation}

In response to such criticism, scholars have provided moral, policy and process-based responses to such critiques. On moral grounds, it has been suggested that ${ }^{130}$ settlement can be justified on the basis of values including consistency, participation, empowerment, dignity, respect, empathy, catharsis, privacy, efficiency, quality, equity, access and justice. ${ }^{131}$ From this perspective, settlement does not preclude the use or creation of precedent while secrecy may be useful in some cases, providing greater possibilities for just results, and deeper and richer access to justice. ${ }^{132}$ In addition, settlements absent consensus should not be enforced. ${ }^{133}$ Scholars have also examined whether justice can be achieved through the court system, ${ }^{134}$ have highlighted the value of reconciliation of broken relationships through ADR, ${ }^{135}$ and have ${ }^{136}$ noted that facilitative mediation contributes to principles of self-determination. ${ }^{137}$

\subsection{CONCLUSION}

This chapter has examined the key intrinsic and extrinsic justifications for the development of court-based mediation, namely, efficiency, reduction of caseloads, private and public sector cost reductions, as well as extrinsic factors including relational, societal and process-based considerations. A range of studies have shed light on the contributions of court-based mediation to the performance of judiciaries in diverse regions. Critiques of court-based mediation likewise raise important considerations for court mediation design and implementation which will be examined through the various case studies and survey research presented in greater detail in the chapters that follow.

130 C. Menkel-Meadow, 'Whose Settlement is It Anyway? A Philosophical and Democratic Defense of Settlement (In Some Cases)' (1995) 83 Georgetown Law Journal 2663; L.P. Love and E. Galton, Stories Mediators Tell (ABA Book Publishing, 2012).

131 Ibid.

132 Ibid.

133 Ibid.

134 A.W. McThenia and T.L. Shaffer, 'For Reconciliation' (1985) 94 Yale Law Journal 1660.

135 Ibid.

136 K.K. Kovach and L.P. Love, "Evaluative" Mediation is an Oxymoron' (1996) 14 Alternatives to High Cost Litigation (March).

137 Ibid. 